\title{
РОЗДІЛ ІІ
}

\section{ПРОБЛЕМИ \\ ДОСУДОВОГО РОЗСЛІДУВАННЯ}

УДК: $343.13 ; 343.98$

DOI: https://doi.org/10.32366/2709-9261-2021-1-1-36-42

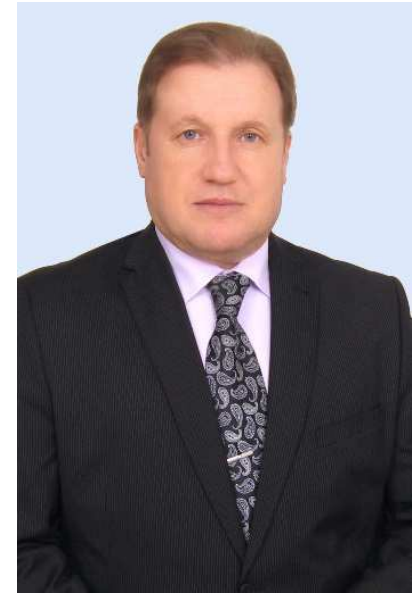

Волобуєв Анатолій Федотович, доктор юридичних наук, професор

(Донецький юридичний інститут МВС України, м. Маріуполь) ORCID: https://orcid.org/0000-0001-9419-7446

Волобуєва Олена Олексіївна, кандидат юридичних наук, професор (Донецький юридичний інститут МВС України, м. Маріуполь) ORCID: https://orcid.org/0000-0002-8601-4344

\section{КРИМІНАЛЬНЕ ПРОВАДЖЕННЯ: ПРОБЛЕМНІ ПИТАННЯ ПОНЯТІЙНО- КАТЕГОРІЙНОГО АПАРАТУ}

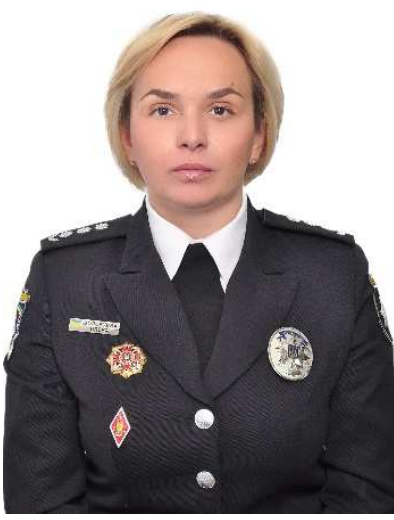

Аналізуються зміни в понятійно-категорійному апараті наук кримінально-правового блоку у зв'язку з оновленням кримінального й кримінального процесуального законодавства України. Відзначається, що нормативне введення в обіг нових категорій без належного теоретичного обґрунтування породжує низку суперечностей під час вирішення багатьох завдань кримінального провадження. Констатується необхідність узгодження понять і категорій галузевих і прикладних наук кримінально-правового блоку, що $є$ запорукою прийняття правильних процесуальних і тактичних рішень під час кримінального провадження. Формулюється висновок, що понятійнокатегорійний апарат набуває ознак системності й несуперечливості тільки тоді, коли процес формування понять і категорій послідовно проходить усі етапи - від теоретичних гіпотез (пропозицій) до їхньої практичної апробації та легалізації.

Ключові слова: кримінальне провадження; поняття; категорії; кримінальне правопорушення; кримінальний проступок; злочин; досудове розслідування.

Постановка проблеми. Під час кримінального провадження вирішується багато проблемних завдань, для чого використовуються знання, накопичені в науках кримінально-правового блоку: кримінального права, кримінального процесу, криміналістики, кримінології, теорії оперативно-розшукової діяльності (далі - ОРД). При цьому особливо важливе місце займає понятійно-категорійний апарат цих наук. Він відіграє визначальну роль у систематизації накопичених знань, а ступінь його сформованості, системності та несуперечливості $\epsilon$ показником зрілості будь-якої галузі науки. 
Проблема формування понятійно-категорійного апарату кримінально-правових наук, його складових понять, категорій (юридичної термінології) має надзвичайно важливе значення і для теорії, і для практики. Сформовані в науках понятяя і категорії виступають, з одного боку, фіксаторами отриманих знань, упорядковують їх, а з іншого - використовуються як інструментарій подальшого пізнання. Правильно сформований понятійно-категорійний апарат кожної з наук кримінально-правового блоку (визначається межами предмета кожної галузевої чи прикладної науки) $€$ одним із пріоритетних наукових завдань і виконує важливу роль на різних стадіях кримінального провадження. Реформування ж в Україні кримінального й кримінального процесуального законодавства, нормативне введення в обіг нових термінів створило певний когнітивний дисонанс у системі понять і категорій, який негативно позначається як на правозастосовчій діяльності, так і на наукових дослідженнях правових явищ. Саме це й обумовило вибір теми даної статті та її мету.

Аналіз останніх досліджень і публікацій. По-перше, потрібно відзначити, що використання термінів «поняття» і «категорія» обумовлено їхнім філософським змістом, відповідно до якого «поняття» виступає формою мислення, що характеризується відображенням закономірних відношень та властивостей об'єктів у вигляді думки про їхні загальні та специфічні ознаки [1, с. 497-498]. Під категоріями розуміються найбільш загальні (стислі), ґрунтовні поняття, що відображають найістотніші, закономірні зв'язки та відносини реальної дійсності [1, с. 272]. Так ці терміни розрізняються, а пов'язані вони тим, що категорія виступає стислим вираженням змісту найбільш ґрунтовних понять. Саме в цьому аспекті вони й використовуються в статті.

По-друге, принципові положення щодо методів і прийомів формування понятійно-категорійних апаратів наук кримінально-правового блоку, їхнього співвідношення і взаємозв'язку були сформульовані в низці наукових праць М.І. Панова [2; 3; 4]. Викладені в них положення використовуються як вихідні у ході розгляду проблемних питань використання окремих понять і категорій у кримінальному провадженні.

Виклад основного матеріалу. Прийняття в 2012 р. нового Кримінального процесуального кодексу України (далі - КПК України) і перманентне внесення змін до кримінального законодавства знаменувалося, з одного боку, введенням у правозастосовчий і науковий обіг низки нових понять, які не відповідали наявному понятійно-категорійному апарату наук кримінально-правового блоку, а з іншого виключенням з обігу традиційних, усталених понять. Це вимагало переосмислення низки теоретичних положень і практичних рекомендацій, що стосувалися, зокрема, підстав відкритя кримінального провадження, загальної процедури збирання доказів, прийняття окремих процесуальних рішень, проведення слідчих (розшукових) дій.

Згідно з існуючою парадигмою формування понятійно-категорійного апарату юридичних наук супроводжується двома взаємопов'язаними процесами доктринальним і легальним. Відповідно всі поняття і категорії, як відзначає М. І. Панов, поділяються на дві великі групи. Доктринальні (курсив наш. - А. В., О. В.) - це ті правові поняття, які, як результат пізнавальної діяльності, належать безпосередньо науці і за допомогою яких виражаються ті чи інші «концепції», «теорії», «учення» юридичної науки. Вони власне і складають зміст юридичної науки як результат пізнавальної діяльності, несуть у собі первинну правову інформацію. Легальні (курсив наш. - А. В., О. В.) - це такі поняття, що одержали нормативне 
закріплення у відповідних нормативно-правових актах: законах і підзаконних актах і належать не тільки юридичній науці. При цьому вони залишаються носіями наукової інформації, зберігаючи, з огляду на їхнє походження, власний статус доктринальних у вигляді результату (зрізу) науково-пізнавальної діяльності. Легальні поняття імперативним шляхом визначають обсяг суспільних відносин, що виступають предметом правового регулювання [2, с. 59-60].

На підставі цього робимо принипово важливий висновок, що легальні понятяя за своїм походженням також $€$ доктринальними (формуються в надрах наук у результаті дискусій та апробацій), але такими, що, маючи статус загальновизнаних, отримують нормативне закріплення і перетворюються в імперативні приписи й правила. Таким чином, «нормальний» процес формування понятійно-категорійного апарату юридичних наук і нормативно-правових актів можна визначити як такий, що включає в себе наступні послідовні етапи: 1) розроблення науковцями понять на рівні гіпотез (обґрунтованих пропозицій); 2) апробація понять на теоретичному рівні (в ході дискусій); 3) апробація понять на практичному рівні (сприйняття юридичною практикою); 4) нормативне закріплення з наведенням дефініцій.

Видається, що реформування кримінального законодавства в Україні супроводжувалося введенням в обіг низки понять (термінів), які не пройшли всієї «нормальної» процедури, як-то кажуть, цей процес було поставлено з ніг на голову. Так, терміни «кримінальне правопорушення» і «кримінальний проступок», які змінили зміст легальної категорії «злочин», з'явилися не в результаті їхнього наукового обгрунтування і навіть не в чинному Кримінальному кодексі України (далі - КК України), а в новому КПК України 2012 р. (і тільки в 2020 р. вони були відтворені в КК України й набули чинності) [5]. Фактично статусний рівень категорії «злочин» нормативно було істотно занижено, що не знайшло попереднього обгрунтування в теорії кримінального права.

Відповідно до ст. 11 КК України кримінальне правопорушення визначається як передбачене кримінальним кодексом суспільно небезпечне винне діяння (дія або бездіяльність), вчинене суб'єктом кримінального правопорушення. Не визнається кримінальним правопорушенням дія або бездіяльність, яка хоча формально й містить ознаки будь-якого діяння, передбаченого цим кодексом, але через малозначність не становить суспільної небезпеки, тобто в результаті цієї дії не було заподіяно й не могло бути заподіяно істотної шкоди фізичній чи юридичній особі, суспільству або державі. Усі кримінальні порушення поділяються на кримінальні проступки й злочини. При цьому кримінальний проступок визначається як діяння (дія чи бездіяльність), за вчинення якого передбачено основне покарання у вигляді штрафу в розмірі не більше трьох тисяч неоподатковуваних мінімумів доходів громадян або інше покарання, не пов'язане з позбавленням волі (тобто через вказівку не на суттєву, а формальну ознаку). Дефініція ж злочину в чинному КК України взагалі не наводиться.

У зв'язку з цим потрібно зазначити, що понятя «проступок» використовується в Кодексі України про адміністративні правопорушення (далі - КУпАП). У ст. 9 КУпАП зазначається, що адміністративним правопорушенням (проступком) визнається протиправна, винна (умисна або необережна) дія чи бездіяльність, яка посягає на громадський порядок, власність, права і свободи громадян, на встановлений порядок управління і за яку законом передбачено адміністративну відповідальність, за умови, що ці порушення за своїм характером не тягнуть за собою відповідно до закону кримінальної відповідальності. Але ні в КК України, ні в КУпАП не вказується 
на сутнісні ознаки-відмінності кримінально караних та адміністративно караних проступків.

Зрозуміло, що виділення групи кримінальних правопорушень, позначених терміном «кримінальні проступки», було пов'язано з намаганням розвантажити органи досудового розслідування в ситуації, коли на одного слідчого припадала величезна кількість кримінальних проваджень (як правило, кілька сотень), що призводило до фактичного колапсу досудового слідства. Для вирішення цієї проблеми створювалися органи дізнання, до компетенції яких і було віднесено розслідування кримінальних проступків. Але що заважало це зробити в межах попередньої парадигми, відповідно до якої виділялася група злочинів, яка позначалася поняттям «злочини невеликої тяжкості»?

Потрібно також зауважити, що виключення з КК України поняття злочину у статусі легальної категорії (з наведенням дефініції) і заміна його на поняття «кримінальне правопорушення» спричиняє необхідність перегляду низки концептуальних положень усіх наук кримінально-правового блоку. Адже такі категорії кримінального права, як «злочин», «склад злочину», «суб'єкт злочину» та подібні були базовими для інших наук для розроблення власних понятійних апаратів. Вони створювали вихідний логіко-юридичний матеріал для прикладних наук. Зокрема, йдеться про визначення предметів наук кримінально-правового блоку, а також процесу створення окремих наукових галузевих учень, у яких використовуються поняття злочину, злочинності, механізму злочину, особи злочинця, слідів злочину та інших (кримінологія, криміналістика, ОРД). Тобто ці поняття виконували функцію впорядкування галузевих знань кримінально-правових наук, надавали їм ознак системності. У сучасних же умовах істотного оновлення базових понять кримінального права постає нагальне завдання перегляду низки концепцій галузевих наук, що обумовлено не природним розвитком цих наук, а тільки фактом використання законодавцем нової термінології, яка не пройшла етапів ії теоретичного осмислення та практичної апробації.

Потрібно також звернути увагу на те, що проблема перевантаження органів досудового розслідування значною мірою була обумовлена й ліквідацією у кримінальному процесі інституту дослідчої перевірки, а також поняття підстав відкриття кримінального провадження (стадія порушення кримінальної справи).

Як відзначає Л. М. Лобойко, під час підготовки проєкту КПК України Національною комісією зі зміцнення демократії і утвердження верховенства права не було іншого більш дискусійного питання, ніж питання про необхідність подальшого існування стадії та рішення про порушення кримінальної справи [6, с. 251-252]. Дискусійність цього питання, на думку автора, була обумовлена розробленням у попередні роки концепції дослідчого кримінального процесу. Відповідно до цієї концепції пропонувалося без порушення кримінальної справи проводити перевірку повідомлення про злочин і збирати докази, а потім передавати зібрані матеріали слідчому для порушення кримінальної справи та пред'явлення особі обвинувачення [7; 8]. Але під час підготовки проєкту КПК України було вирішено, що стадія порушення кримінальної справи, де вирішувалося питання про наявність підстав для кримінального провадження, не потрібна, оскільки $\epsilon$ породженням радянських уявлень про кримінальний процес, про справедливість і законність [6, с. 254-255].

Виключення з кримінального процесу стадії порушення кримінальної справи і разом з нею інституту дослідчої перевірки повідомлень про злочин обумовило появу 
більш складної проблеми в порівнянні зі збереженням радянських уявлень про справедливість і законність. Вона полягає у тому, що слідчий, прокурор під час отримання інформації (зокрема заяви чи повідомлення) про вчинення кримінального правопорушення зобов'язуються невідкладно (але не пізніше 24 годин) внести відповідні відомості до Єдиного реєстру досудових розслідувань (далі - ЄРДР), розпочати розслідування та через 24 години з моменту внесення таких відомостей надати заявнику витяг з ЄРДР (ч. 1 ст. 214 КПК України). Тобто орган досудового розслідування не зобов'язується перевіряти заяву (повідомлення) на предмет наявності підстав для проведення досудового розслідування - ознак кримінального правопорушення (злочину). Досудове розслідування повинно починатися невідкладно, відразу після внесення отриманих відомостей про кримінальне правопорушення до ЄРДР.

Як цілком слушно звернув увагу Д. В. Філін, за ст. 214 КПК України початок досудового розслідування повинен відбуватися фактично після технічної реєстрації таких заяв і повідомлень. Тобто законодавець пов'язав початок досудового слідства не з прийняттям процесуального рішення про встановлення ознак злочину, а 3 внесенням запису про отримання інформації про вчинений злочин до ЄРДР. Однак таке враження, як відзначає згаданий автор, є оманливим, адже низка норм КПК України (ст. 60, 4. 8 ст. 95, ст. 110, ст. 214, ст. 303), а також відомчих нормативних актів, які регулюють порядок прийняття та реєстрації заяв і повідомлень про злочини, містить як способи перевірки достовірності заяв і повідомлень про кримінальні правопорушення, так і можливість прийняття процесуальних рішень, аналогічним тим рішенням, які приймалися за попереднім законодавством на стадії порушення кримінальної справи [9].

Але як би там не було, імперативний припис ст. 214 КПК України зобов'язує невідкладно починати досудове розслідування після реєстрації заяв і повідомлень про кримінальне правопорушення. Складається враження, що саме це положення відкрило «шлюзи» для величезної кількості заяв про нібито кримінальні правопорушення з вимогою захисту порушених прав за допомогою кримінальноправових засобів. Це дуже швидко призвело до перевантаження органів досудового розслідування, коли в провадженні кожного слідчого опинилося кілька сотень справ (а іноді й більше 1000). По суті слідчі підрозділи перетворилися на реєстраторів і накопичувачів матеріалів кримінальних проваджень. У створених умовах не могло йтися про реальне та ефективне розслідування, воно досить часто перетворювалося на його імітацію. Як швидко виявилося, значна кількість таких заяв і повідомлень стосувалася правопорушень не кримінальних, а зовсім інших (адміністративних, цивільних, господарських та под.), а іноді й умисних неправдивих повідомлень про нібито вчинене кримінальне правопорушення. Л. Д. Удалова наводить статистичні дані Генеральної прокуратури України, відповідно до яких переважна більшість розпочатих кримінальних проваджень закривається за відсутності події чи складу кримінального правопорушення [10, с. 234-235]. Отже, постає питання про необхідність збільшення проміжку часу між отриманням правоохоронним органом повідомлення про кримінальне правопорушення і початком досудового розслідування, який повинен бути призначений для проведення перевірочних заходів слідчим або органом дізнання.

Висновки. Підсумовуючи викладене, можна зробити висновок, що розробленість понятійно-категорійного апарату наук кримінально-правового блоку (його системність та несуперечливість) $€$ важливим інструментом пізнавальної 
діяльності і в наукових дослідженнях, і в практичній діяльності кримінального провадження. Але таких ознак він набуває тільки тоді, коли процес формування понять і категорій послідовно проходить усі необхідні етапи - від теоретичних гіпотез (пропозицій) до їхньої практичної апробації та легалізації. В іншому випадку, як показує досвід, - не уникнути прогалин і суперечностей у законодавстві і в наукових концепціях, які ставлять, зокрема, органи досудового розслідування у глухий кут та обумовлюють прийняття сумнівних рішень в умовах змагального процесу.

Висловлена позиція, звичайно, стосується окремих проблемних понять і категорій, не претендує на статус абсолютної істини й визнання та є запрошенням до подальшого аналізу окресленої проблематики.

\section{Список використаних джерел}

1. Філософський енциклопедичний словник. Київ: Абрис, 2002. 742 с.

2. Панов М. Проблеми формування понятійного апарату юридичної науки: методологічні аспекти. Вісник Академії правових наук України. 2003. № 2-3 (33-34). С. 54-67.

3. Панов М. Понятійний апарат кримінального права та його науково-практичне значення. Право України. 2018. № 4. С. 205-222.

4. Панов М. І. Про співвідношення і взаємозв'язок понятійних апаратів наук кримінального блоку. Проблеми законності. 2019. Вип. 146. С. 158-170.

5. Про внесення змін до деяких законодавчих актів України щодо спрощення досудового розслідування окремих категорій кримінальних правопорушень : Закон України № 2617-VIII від 22.11.2018. URL: https://zakon.rada.gov.ua/laws/show/2617-19 (дата звернення: 05.01.2021).

6. Лобойко Л. М. Реформування кримінально-процесуального законодавства в Україні (2006-2011 роки). Частина 1. Загальні положення і досудове провадження : монографія. Київ: Істина, 2012. 288 c.

7. Зеленецький В. С. Дослідче провадження про вчинений злочин : наук.-практ. посіб. Х.: Право, 2009. $128 \mathrm{c}$.

8. Зеленецкий В. С., Лобойко Л. Н. Доследственный уголовный процесс : монография. Донецк: ООО «Схід. видав. дім», 2012. 397 с.

9. Филин А. В. Начало досудебного производства в уголовном процессе Украины. URL: https://www.iuaj.net/node/1462 (дата звернення: 05.01.2021).

10. УдаловаЛ.Д. Проблемні питання початку досудового розслідування. Юридичний часопис Національної академії внутрішніх справ. 2016. № 1 (11). С. 228-237.

\section{References}

1. Filosofskyi entsyklopedychnyi slovnyk [Philosophical encyclopedic dictionary]. Kyiv: Abrys, 2002. 742 s. [in Ukrainian].

2. Panov, M. (2003). Problemy formuvannia poniatiinoho aparatu yurydychnoi nauky: metodolohichni aspekty [Problems of formation of the conceptual apparatus of legal science: methodological aspects]. Visnyk Akademii pravovykh nauk Ukrainy. № 2-3 (33-34). S. 54-67 [in Ukrainian].

3. Panov, M. (2018). Poniatiinyi aparat kryminalnoho prava ta yoho naukovo-praktychne znachennia [The conceptual apparatus of criminal law and its scientific and practical significance]. Pravo Ukrainy. № 4. S. 205-222 [in Ukrainian].

4. Panov, M. I. (2019). Pro spivvidnoshennia i vzaiemozviazok poniatiinykh aparativ nauk kryminalnoho bloku [On the relationship and interrelation of the conceptual apparatus of the sciences of the criminal bloc]. Problemy zakonnosti. 2019. Vyp. 146. S. 158-170 [in Ukrainian].

5. Pro vnesennia zmin do deiakykh zakonodavchykh aktiv Ukrainy shchodo sproshchennia dosudovoho rozsliduvannia okremykh katehorii kryminalnykh pravoporushen : Zakon Ukrainy № 2617-VIII vid 22.11.2018 [On Amendments to Certain Legislative Acts of Ukraine Concerning Simplification of Pre-trial Investigation of Certain Categories of Criminal Offenses : Law of Ukraine]. URL: https://zakon.rada.gov.ua/laws/show/2617-19 (data zvernennia: 05.01.2021) [in Ukrainian].

6. Loboiko, L. M. (2012). Reformuvannia kryminalno-protsesualnoho zakonodavstva v Ukraini (20062011 roky). Chastyna 1. Zahalni polozhennia i dosudove provadzhennia : monohrafiia [Reform of criminal procedure legislation in Ukraine (2006-2011). Part 1. General provisions and pre-trial proceedings : a monograph]. Kyiv: Istyna. 288 s. [in Ukrainian]. 
7. Zelenetskyi, V.S. (2009). Doslidche provadzhennia pro vchynenyi zlochyn : nauk.-prakt. posib. [Research proceedings on the committed crime]. Kh.: Pravo.128 s. [in Ukrainian].

8. Zeleneckij, V.S., Lobojko, L.M. (2012). Dosledstvennyj ugolovnyj process : monografiya [Investigative criminal process : a monograph]. Doneck: OOO «Skhid. vidav. dim». $397 \mathrm{~s}$. [in Russian].

9. Filin, D. V. Nachalo dosudebnogo proizvodstva $v$ ugolovnom processe Ukrainy [Start of pre-trial proceedings in the criminal procedure of Ukraine]. URL: https://www.iuaj.net/node/1462 (data zvernennia: 05.01.2021) [in Russian].

10. Udalova, L. D. (2016). Problemni pytannia pochatku dosudovoho rozsliduvannia [Problematic issues of the beginning of the pre-trial investigation]. Yurydychnyi chasopys Natsionalnoi akademii vnutrishnikh sprav. № 1 (11). S. 228-237 [in Ukrainian].

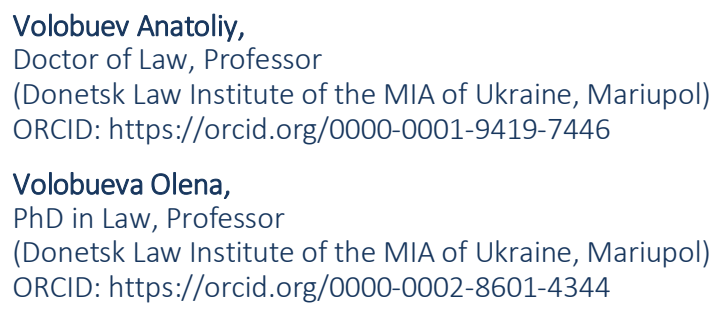

CRIMINAL PROCEEDINGS: ISSUES OF THE CONCEPTING-CATEGORIAL APPARATUS

The article analyzes the changes in the conceptual and categorical apparatus of the sciences of the criminal-legal block in connection with the updating of the criminal and criminal procedural legislation of Ukraine. Reforming of criminal and criminal procedural legislation in Ukraine, normative introduction of new terms has created a certain cognitive dissonance in the system of concepts and categories, which negatively affects both law enforcement activities and research of legal phenomena. It is noted that the normative introduction of new categories into circulation without proper theoretical justification generates a number of contradictions in solving many problems of criminal proceedings. The necessity of bringing the concepts and categories of the branch and applied sciences of the criminal-legal block to a systematic nature is stated, which is the key to making correct procedural and tactical decisions in the course of criminal proceedings. The conclusion is formulated that the conceptual-categorical apparatus acquires the qualities of systematic and consistency only when the process of forming concepts and categories consistently goes through all the stages - from theoretical hypotheses (sentences) to their practical testing and legalization. The development of the conceptual and categorical apparatus of the sciences of the criminal law block (its system and consistency) is an important tool of cognitive activity in research and in the practical activities of criminal proceedings. As experience shows, it is inevitable to avoid gaps and contradictions in legislation and scientific concepts, which put, in particular, pretrial investigation bodies, in a dead end and cause dubious decisions in the conditions of adversarial process. The stated position, of course, concerns certain problematic concepts and categories, does not claim the status of absolute truth and recognition and is an invitation to further analysis of this issue.

Key words: criminal proceedings; concepts; categories; criminal offense; criminal offense; crime; pre-trial investigation.

Надійшла до редколегії 13.01.2021 